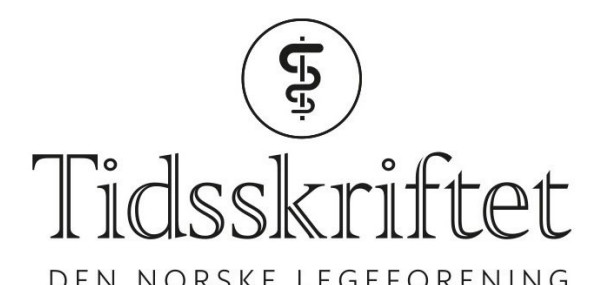

DEN NORSKE LEGEFORENING

\title{
Hvorfor velger leger seg bort fra allmennmedisin?
}

ORIGINALARTIKKEL

\section{CECILIE NORMANN BIRKELI}

E-post: cecilie.normann@legeforeningen.no LEFO - Legeforskningsinstituttet

Hun har bidratt med idé, utforming/design, datainnsamling, tolkning av data, førsteutkast og revisjon av manus og godkjenning av innsendte manusversjon.

Cecilie Normann Birkeli er ph.d.-kandidat, M.H.Sc. og rådgiver.

Forfatteren har fylt ut ICMJE-skjemaet og oppgir ingen interessekonflikter.

\section{JUDITH ROSTA}

LEFO - Legeforskningsinstituttet

Hun har bidratt med utforming/design, datainnsamling, tolkning av data, utarbeiding og revisjon av manus og godkjenning av innsendte manusversjon.

Judith Rosta er M.A., ph.d. og seniorforsker.

Forfatteren har fylt ut ICMJE-skjemaet og oppgir ingen interessekonflikter.

\section{OLAF GJERLØW AASLAND}

LEFO - Legeforskningsinstituttet

Han har bidratt med utforming/design, tolkning av data, grafisk framstilling av figurer, utarbeiding og revisjon av manus og godkjenning av innsendt manus.

Olaf Gjerløw Aasland er lege, M.H.A. og seniorforsker.

Forfatteren har fylt ut ICMJE-skjemaet og oppgir ingen interessekonflikter.

\section{KARIN ISAKSSON RØ}

LEFO - Legeforskningsinstituttet

Hun har bidratt med utforming/design, datainnsamling, tolkning av data, utarbeiding og revisjon av manus og godkjenning av innsendte manusversjon.

Karin Isaksson Rø er ph.d, M.H.A., spesialist i arbeidsmedisin og instituttleder.

Forfatteren har fylt ut ICMJE-skjemaet og oppgir ingen interessekonflikter.

\section{BAKGRUNN}

Det har vært mye fokus på manglende rekruttering til allmennmedisin i norsk politikk, media og forskning. Vi vet lite om hvilke grunner som har vært viktige for leger som aktivt har valgt bort allmennmedisin. Vi ville derfor undersøke hvilke leger som velger seg bort fra allmennmedisin, og hvorfor. 
Dataene baserer seg på et spørreskjema sendt til Legepanelets 2195 medlemmer i 2016/17. Svarprosenten var 73,1. Vi brukte grafikk og deskriptive analyser for å studere forskjeller mellom de som hadde vurdert allmennmedisin og likevel ikke valgt det, og de som hadde sluttet i allmennmedisin.

\section{RESULTATER}

Av 1153 leger som ikke var allmennleger/fastleger, hadde 44,1\% heller ikke vurdert å bli det. $39,9 \%$ hadde vurdert, men likevel ikke valgt det, og $16,0 \%$ hadde jobbet som fastlege/allmennlege, men sluttet. Administrativ byrde og lite faglig miljø var de viktigste årsakene til at leger valgte seg bort fra allmennmedisin.

\section{FORTOLKNING}

Administrativ byrde og lite faglig miljø var viktige årsaker til at leger enten valgte bort allmennmedisin eller sluttet i faget. Også flere andre årsaker spilte inn, og arbeidet med å rekruttere og beholde allmennleger bør derfor ses i en større og mer helhetlig sammenheng.

Det har lenge vært oppmerksomhet rundt manglende rekruttering til allmennmedisin (1-7). I en evaluering fra $2016(8,9)$ oppga hver fjerde turnuslege at de ønsket å begynne i allmennmedisin. Behovet for nye fastleger er imidlertid mye større (2). I tidligere studier har man kartlagt hvilke faktorer fastleger selv mener er viktige for å rekruttere og beholde leger i faget. Ved også å spørre leger som har valgt bort eller sluttet $\mathrm{i}$ allmennmedisin, kan vi få ytterligere kunnskap om forhold som påvirker dette valget.

Rekruttering og stabilitet er vist å være viktig for å få nok leger totalt i faget og for å få fastleger til å velge å jobbe i distriktene $(4,10)$. Behov for økonomisk trygghet samt lønns- og arbeidsvilkår, blant annet grad av arbeidsbelastning, antas å være faktorer som bidrar til at man velger bort allmennmedisin (1). Norske studier har vist at faglig utvikling, profesjonell autonomi, kontroll over egen arbeidstid og subjektivt håndterlig størrelse på praksis er viktig for å fortsette å arbeide i allmennmedisin $(3,11)$. Studier fra andre land viser at $\emptyset$ konomiske incentiver kan ha positiv effekt på rekruttering til usentrale strøk, men faglig innhold og utviklingsmuligheter synes å spille en større rolle $(12,13)$.

Innføring av samhandlingsreformen i 2012 medførte $ø$ kt arbeidsvolum og oppgaveoverføring fra spesialisthelsetjenesten til primærhelsetjenesten $(14,15)$. På tross av at gjennomsnittlig listelengde er redusert med $6 \%$ i perioden 2010-17, viser data fra Statistisk sentralbyrå at det har vært en større vekst i fastlegenes arbeidsbelastning enn i tilgjengelige legeressurser (16).

En rapport fra Danmark viser at andelen allmennpraktiserende leger som ikke var tilfredse i jobben, økte fra $6 \%$ i 2012 til $22 \%$ i 2016 (17). Dette hadde sammenheng med et høyere antall arbeidstimer, dårlige lønnsforhold, manglende anerkjennelse for vel utført jobb og manglende frihet til å velge arbeidsmåte. I Sverige viste beregninger fra 2014 at hvis man tok utgangspunkt i en legedekning på 1500 pasienter per lege i 2017, ville man trenge dobbelt så mange allmennleger (18). I forlengelsen av dette avdekket man i en kvalitativ studie at opplevelsen av høy arbeidsbelastning og lav bemanning gjorde legevirksomheten mindre meningsfylt og skapte flere utfordringer. Kontroll over egen arbeidshverdag og mulighet til å planlegge arbeidstiden, også for å kunne jobbe deltid, ble løftet som viktige kriterier i valg 
av spesialitet (18).

I England viste en studie at $ø$ kt arbeidsbyrde og lengre arbeidsuker for allmennpraktikere var de vanligste årsakene til at man pensjonerte seg tidligere enn opprinnelig planlagt (19). De fleste allmennlegene opplevde dessuten liten effekt av nasjonale tiltak som ble satt i gang for å avhjelpe den sviktende rekrutteringen.

I tidligere studier har man primært undersøkt hva fastlegene selv mener om faktorer som påvirker rekruttering til allmennmedisin og om man blir i faget. For å få innsikt i hvilke grunner som har vært viktige for leger som har valgt seg bort fra allmennmedisin, vil vi derfor se nærmere på hvilke leger som velger bort en slik karriere og hvorfor.

\section{Materiale og metode}

Legeforskningsinstituttet (LEFO) brukte legepanelet, som består av 2195 medlemmer. Dette er et utvalg av yrkesaktive leger som er blitt fulgt med postale spørreskjemaer siden 1994. Representativitet i forhold til alder, kjønn og stilling opprettholdes ved at yngre leger tas inn når legene pensjoneres, dør eller av andre grunner går ut av utvalget. De aktuelle dataene ble samlet inn fra panelet i november 2016 - mars 2017, med to purringer. Spørreundersøkelsen er godkjent av Norsk senter for forskningsdata (NSD). Undersøkelsen var ikke framleggelsespliktig for Regional komité for medisinsk og helsefaglig forskningsetikk (IRB oooo 1870).

Til leger som ikke jobbet i allmennpraksis på det aktuelle tidspunktet, stilte vi spørsmålet: «Vurderte du noen gang å bli allmennlege/fastlege?», med svaralternativene «nei», «ja» og «ja, og jeg har vært allmennlege/fastlege, men har sluttet». De som hadde vurdert fastlege/allmennlege, men valgt det bort og de som hadde sluttet $\mathrm{i}$ allmennpraksis, gikk videre til spørsmål om hvilke av 17 ulike faktorer som bidro til at de ikke lenger var fastleger. Det var tre svaralternativer for hver faktor (ja/nei/ikke aktuelt). De som svarte «andre årsaker», fikk muligheten til å spesifisere nærmere i et kommentarfelt. Spørsmålene ble utviklet av LEFO-forskere i samarbeid med tillitsvalgte i Allmennlegeforeningen.

Vi presenterer deskriptive data om leger som vurderte å bli allmennlege/fastlege, men ikke ble det, og leger som har vært fastleger, men sluttet i faget. Respondenter med manglende data ble ekskludert fra analysene. Dataene ble registrert og analysert med SPSS versjon 25.

\section{Resultater}

Alt i alt svarte 1604 av 2 195 (73,1\%) på undersøkelsen. 44 av disse var > 70 år og ble derfor ekskludert. Av de gjenværende 1560 var $287(18,4 \%)$ fastleger, og dermed ikke aktuelle for videre analyser. Av de resterende 1273 legene var det 1153 som både hadde svart nei på spørsmål om de var fastleger og hadde besvart spørsmålet om de noensinne hadde vurdert å bli fastleger. Det vil si at vi mangler data for 120 av 1273 (9,4\%).

Av de 1153 som svarte på spørsmålet om de noen gang vurderte å bli allmennlege/fastlege svarte 508 (44,1\%) nei, 46o (39,9\%) ja, og 185 (16,0 \%) at de hadde vært allmennlege/fastlege, men sluttet.

En større andel av kvinnene (294/641; 45,9\%) enn mennene (166/512;32,4\%) hadde vurdert, men valgt bort, allmennpraksis. Samtidig hadde en større andel av mennene (104/512; $20,3 \%$ ) enn kvinnene $(81 / 641 ; 12,6 \%)$ vært allmennleger og sluttet. $287 / 471(60,9 \%)$ av legene i alderen 25-35 år hadde vurdert, men valgt bort, allmennmedisin, mot 94/254 (37,0 \%) av dem i alderen 36-45 år og 43/184 (23,4\%) i alderen 46-55 år (tabell 1).

\section{Tabell 1}

Prosentvis fordeling av svar på spørsmålet «Vurderte du noen gang å bli 
allmennlege/fastlege?» Spørsmålet ble stilt i 2016-17 til de leger i Legeforskningsinstituttets legepanel som på det tidspunktet ikke var allmennleger/fastleger $(\mathrm{N}=1153)$.

\begin{tabular}{|c|c|c|c|}
\hline & Nei & Ja & $\begin{array}{l}\text { Ja, og jeg har vært } \\
\text { allmennlege/fastlege, men har } \\
\text { sluttet }\end{array}$ \\
\hline \multicolumn{4}{|l|}{ Kjønn } \\
\hline Menn $(n=512)$ & 47,3 & 32,4 & 20,3 \\
\hline Kvinner $(n=641)$ & 41,5 & 45,9 & 12,6 \\
\hline \multicolumn{4}{|l|}{ Alderskategorier (år) $)^{1}$} \\
\hline $25-35(n=471)$ & 31,2 & 60,9 & 7,9 \\
\hline $36-45(n=254)$ & 53,1 & 37,0 & 9,9 \\
\hline $46-55(n=184)$ & 56,0 & 23,4 & 20,6 \\
\hline $56-69(n=224)$ & 51,3 & 14,3 & 34,4 \\
\hline \multicolumn{4}{|l|}{ Hovedstilling innenfor fagområde ${ }^{2}$} \\
\hline Allmennmedisin $(n=82)$ & 15,8 & 62,2 & 22,0 \\
\hline Laboratoriefag $(n=89)$ & 56,2 & 32,6 & 11,2 \\
\hline Indremedisinske fag $(\mathrm{n}=415)$ & 48,9 & 39,5 & 11,6 \\
\hline Kirurgiske fag $(n=275)$ & 55,3 & 35,6 & 9,1 \\
\hline Psykiatri $(n=161)$ & 28,6 & 38,5 & 32,9 \\
\hline Samfunnsmedisin $(n=27)$ & 22,2 & 11,1 & 66,7 \\
\hline Annet $(n=61)$ & 27,9 & 59,0 & 13,1 \\
\hline
\end{tabular}

${ }^{1}$ Alder ikke angitt hos 20 av legene

${ }^{2}$ Spesialistgruppe ikke angitt hos 43 av legene

Blant dem som hadde sluttet i allmennpraksis, var det en større andel av kvinnene (33/80; $41,3 \%$ ) enn mennene (20/100; 20,0 \%) som hadde valgt psykiatri. Den andre hovedspesialiteten som tidligere allmennleger nå særlig jobbet innenfor, var indremedisin (kvinner 17/80; 21,3\% og menn 31/100; 31,0\%).

Av legene i dette utvalget som svarte nei på at de var fastleger, oppga 82 at de i sin hovedstilling arbeidet innen allmennmedisin. 38 av disse var turnusleger, 5 var sykehusleger, 13 jobbet i kommunehelsetjenesten, 4 med forskning, 12 oppga annet og 10 at de jobbet $\mathrm{i}$ allmennpraksis.

Figur 1 viser 16 årsaker til å velge bort og slutte i allmennpraksis, rangert etter synkende andel i prosent for de som valgte seg bort fra allmennmedisin, sammenlignet med andel i prosent for de som har sluttet. 


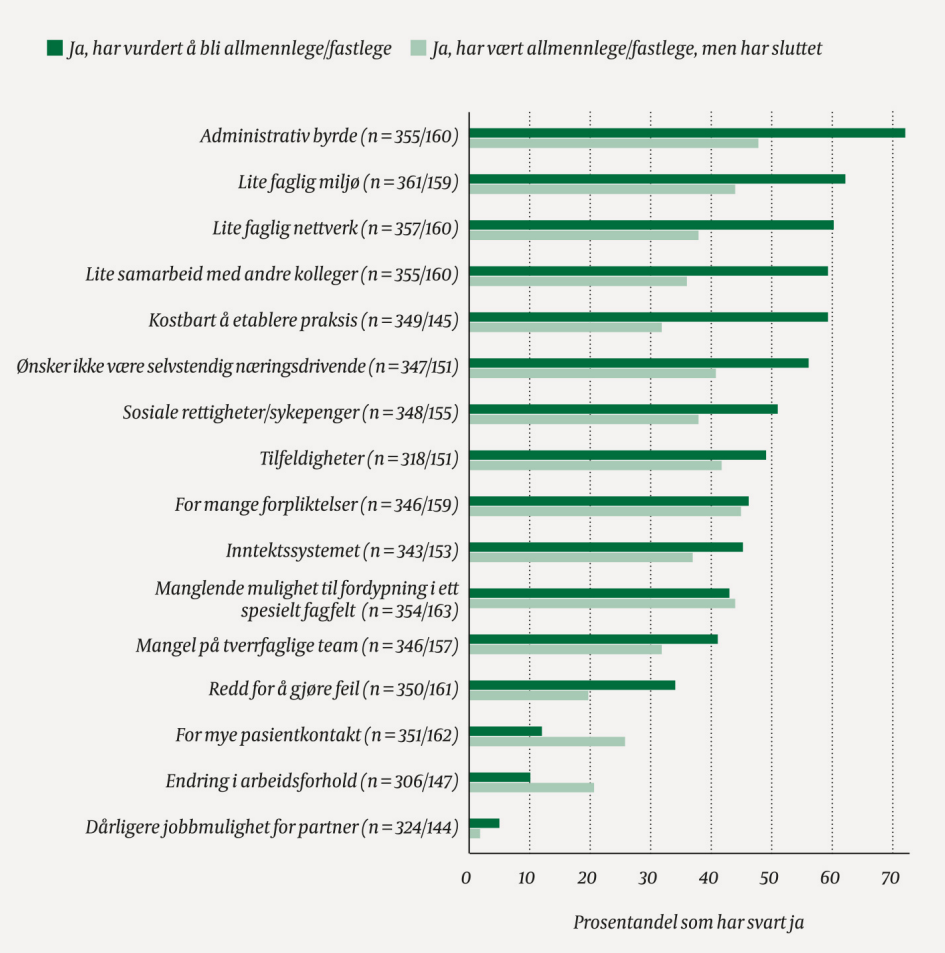

Figur 1 Årsaker til å velge bort allmennpraksis og til å slutte i allmennpraksis blant leger $i$ Legeforskningsinstituttets legepanel som i 2016-17 ikke var allmennleger/fastleger $(N=1153)$. Søylene viser prosentandel i hver kategori som har krysset av på ja. Tallene i parentes på Y-aksen viser totalantallet som har svart ja eller nei på hvert spørsmål for hhv. de som har valgt bort og de som har sluttet. Endring i arbeidsforhold innebcerer her samarbeid med kommunen, skifte av arbeidsgiver etc.

I tillegg til de foreslåtte årsakene ble det i fritekstfelt oppgitt disse årsakene til å velge seg bort fra allmennmedisin: 57 oppga andre planer/interessefelt, 30 at de var turnuslege/ikke hadde valgt enda, 19 svarte vaktbelastning/arbeidsbelastning, 13 svarte at de hadde dårlig erfaringer fra praksis/turnus, og 8 oppga familiære grunner (som f.eks. flytting, alder, sykdom og liten kommune) og 13 svarte annet. Øvrige 42 kommentarer viste til faktorer allerede nevnt i figur 1.

\section{Diskusjon}

Over halvparten av respondentene som ikke jobbet som fastleger, hadde enten vurdert allmennmedisin og ikke valgt det, eller hadde vært allmennlege/fastlege og sluttet i faget. Flere kvinner (enn menn) og flere unge leger hadde vurdert å begynne med allmennmedisin. De viktigste årsakene til at leger valgte seg bort fra allmennmedisin, var administrativ byrde og lite faglig miljø. Når såpass mange av de oppgitte årsaksfaktorene kom høyt opp, antyder det at årsakene er sammensatte. Det er verdt å merke seg at «for mange forpliktelser» synes å være en viktig årsak til å velge seg bort.

Gjentakende studier har vist at fastleger har lengre arbeidsuker enn de fleste andre leger $(20,21)$. I 2018 ble gjennomsnittlig lengde på en arbeidsuke for fastleger målt til 56 timer (22). Den samme studien viste at fastleger har flere oppgaver enn tidligere, for eksempel ekonsultasjoner, attester/erklæringer og dialogmøter. En rapport fra Helsedirektoratet viser at hver pasient har flere konsultasjoner enn før (2). Dette tyder på at de sykdomsforløpene som skal håndteres i allmennpraksis, er blitt mer kompliserte enn tidligere, og at terskelen for å oppsøke fastlege er blitt lavere.

Leger i denne studien mener at for mange forpliktelser og for stor administrativ byrde har bidratt til at de velger seg bort fra allmennmedisin. Studier fra andre land viser at administrativ byrde har $\emptyset \mathrm{kt}$ betraktelig blant allmennpraktikere og at dette oppleves å ta tid fra pasientbehandlingen (19). Oppgaver som gir lengre arbeidstid, kan være vanskelig å forene med legers $\emptyset$ kende $\emptyset$ nske om bedre balanse mellom hjem og jobb $(23,24)$. I en norsk 
studie påpekes betydningen av en god jobb-hjem-balanse, med mulighet for å kunne jobbe deltid - særlig blant kvinner - for å redusere risikoen for jobb-hjem-stress og dermed utbrenthet (24).

Behovet for mer kunnskap om sykdomsforløp og ansvar for pakkeforløp og oppfølging fra spesialisthelsetjenesten som er overført til primærhelsetjenesten kan ha vært undervurdert i innføringen av helsereformer (5). Helseforetaksreformen og Samhandlingsreformen, som blant annet innebærer tidligere overføring av pasienter fra sykehus til primærhelsetjeneste og forventning om mer desentralisert behandling (f.eks. pakkeforløp for kreft), kan ha økt behovet for fagkunnskap og dermed gode faglige miljøer og faglige nettverk for fastleger. Redusert liggetid i sykehus, økende pasientforventninger og tilgang til kunnskap om medisinske problemstillinger knyttet til pasientens egen helse stiller krav til utvidet kunnskap hos fastleger $(5,15)$. Med denne utviklingen blir behovet for faglig miljø tydelig.

Tilfredsheten blant fastlegene har sunket de siste årene. De viktigste grunnene er mangel på anerkjennelse for godt arbeid, mindre frihet til å velge metoder, stor mengde ansvar, lang arbeidstid og utilstrekkelig økonomisk utbytte (25). Leger som velger seg bort fra allmennmedisin, oppgir som viktige faktorer at det er vanskelig å være selvstendig næringsdrivende, at det koster mye å etablere egen praksis og at det er mangel på sosiale rettigheter og trygd. For å få spesialister i allmennmedisin har man på Vestlandet fått statlig støtte til et prøveprosjekt i tidsrommet 2017-22 der man ansetter leger i faste opplæringsstillinger (allmennleger i spesialisering, ALIS). Fastleger som er med i prosjektet, mener at fast lønn, sosial trygghet, kortere lister og god veiledning i denne type stillinger vil $\emptyset$ ke rekrutteringen til allmennmedisin (26). I våre data finner vi at "tilfeldigheter» hyppig ble oppgitt som årsak til bortvalg i gruppen av leger som hadde vurdert, men valgt bort, allmennmedisin. Dette kan være et uttrykk for at spesialitetsvalg styres mer av hvilke muligheter man faktisk får underveis i utdanningsløpet og når og hvor man får disse mulighetene (27). Tilbud om ALIS-stillinger kan dermed ha stor betydning. Samtidig som det i flere kommuner er vanskelig å få søkere til fastlegestillinger (4), er det mange søkere til ALIS-stillingene.

I studier er det foreslått at man bør jobbe mer systematisk med forbedringstiltak for å ivareta legenes egen helse og skape entusiasme for faget $(28,29)$. Her foreslås blant annet en forandret oppgavefordeling, som å flytte en del av de administrative oppgavene til andre. Sykepleiere og annet medisinsk hjelpepersonale kan få utvidet rolle i planlegging og ansvar for forebygging, etter anbefaling fra legen. For å unngå for fragmentert og uoversiktlig oppgavefordeling ville dette kreve gode konsekvensutredninger og stille store krav til samhandling $(30,31)$.

Tiltak som kan bidra til en bedre balanse mellom jobb og hjem gir stabilitet i hverdagslivet og er viktig for en god karriere i allmennpraksis. Slike forhold har vært mye diskutert i allmennlegenes egne fora og i media generelt de siste årene (30, 31, 32). Funnene i denne studien bidrar med ytterligere kunnskap om forhold som påvirker hvorvidt leger velger allmennmedisin og om de blir i spesialiteten.

\section{STYRKER OG BEGRENSNINGER}

Siden tidligere studier har fokusert på hva allmennlegene selv mener er viktige faktorer for valg av faget, er det en styrke at vi også har studert dem som har valgt seg bort fra allmennmedisin. Den høye svarprosenten (73,1\%) gir god representativitet.

En begrensning ved denne studien er at de årsaksfaktorene vi har spurt om, ikke nødvendigvis favner alle fastlegenes arbeidsbelastninger, som for eksempel vaktordninger. Siden forskjellene i vaktbelastning er svært ulike i storbyer sammenlignet med distrikt, valgte vi heller å spørre mer generelt om arbeidsbelastning. Manglende data utgjør 9,4\% i datamaterialet vårt. Dette har sannsynligvis ikke stor betydning for resultatenes validitet. 


\section{Konklusjon}

Administrativ byrde og lite faglig miljø var de viktigste årsakene til at leger velger seg bort fra allmennmedisin. Funnene indikerer imidlertid at bildet er sammensatt. Det er derfor viktig å vurdere flere forhold både for å få flere unge leger til å velge allmennmedisin og for å beholde leger i faget. Diskusjonen om hvorfor det er vanskelig å rekruttere og å holde på leger i allmennmedisin, kan hittil i for stor grad ha dreid seg om enkeltårsaker. Denne studien tyder på at både evaluering av prosjekter med faste stillinger og strukturert veiledning for leger i spesialisering er viktig å gjennomføre og ta konsekvensene av. Samtidig peker den på betydningen av bedre faglige nettverk og faglig oppdatering samt reduksjon av arbeidsbelastning og arbeidstid. En slik kombinasjon av ulike tiltak kan ha betydning for å rekruttere og å beholde leger i allmennpraksis.

\section{HOVEDFUNN}

Over halvparten av respondentene hadde enten vurdert allmennmedisin, men valgt det bort, eller sluttet som allmennlege.

Administrativ byrde og lite faglig miljø var viktige årsaker til at leger valgte seg bort fra allmennmedisin, i tillegg til flere andre faktorer.

\section{LITTERATUR:}

1. Øren TO. Flere unge må velge allmennmedisin. Dagens Medisin 1.4.2017.

https://www.dagensmedisin.no/artikler/2017/04/o1/flere-unge-ma-velge-allmennmedisin/ Lest 20.12.2019.

2. Utvikling i bruk av fastlege og legevakt 2010-2016. Analysenotat i Samdata kommune. Oslo: Helsedirektoratet, 2018. https://www.helsedirektoratet.no/rapporter/utvikling-i-bruk-av-fastlege-og-legevakt-2010-2016/ Lest 10.12.2019.

3. Holte JH. Remuneration and organization in general practice: Three essays on doctors'preferences. Doktoravhandling. Tromsø: UiT - Norges Arktiske Universitet, 2015. https://munin.uit.no/handle/10037/8259 Lest 20.12.2019.

4. Sæther AS, Nærø AF. Kampen om fastlegene. VG 2018. https://www.vg.no/spesial/2017/fastleger/ Lest 10.12.2019.

5. Fastlegeordningen 2.o.Trønderopprørets fastlegeundersøkelse og helsemedarbeiderundersøkelse. Trondheim: Trønderopprøret, 2018.

http://www.flo2o.no/wp-content/uploads/2018/o6/TOundersøkelse-2.pdf Lest 10.12.2019.

6. Westnes SL, Kristoffersen EA, Burman RA. Fastlegeordningen trenger flere leger. Tidsskr Nor Legeforen 2012; 132: 674-6. [CrossRef]

7. Sollien K. Fastlegene flykter fra distriktene. Dagens Medisin 1.2.2016.

https://www.dagensmedisin.no/artikler/2016/02/o1/fastlegene-flykter-fra-distriktene/ Lest 10.12.2019.

8. Birkeli CN. Nasjonal evaluering av turnustjenesten for leger. Rapport. Oslo: LEFO -

Legeforskningsinstituttet, 2015.

https://www.legeforeningen.no/contentassets/ea5f46eb1dc7453d91502248df658427/turnusrapporten-n asjonal-evaluering-av-turnustjenesten-2010.pdf Lest 20.12.2019.

9. Birkeli C. Motiverte turnusleger starter i allmennpraksis, men blir de værende? Tidsskr Nor Legeforen 2016; 136:1261. [PubMed][CrossRef]

10. Legeforeningen. Fastlegesituasjonen forverret, viser ny kartlegging.

https://www.legeforeningen.no/nyheter/2019/fastlegesituasjonen-forverret-viser-ny-kartlegging/ Lest 10.12.2019.

11. Holte JH, Kjaer T, Abelsen B et al. The impact of pecuniary and non-pecuniary incentives for 
attracting young doctors to rural general practice. Soc Sci Med 2015; 128: 1-9. [PubMed][CrossRef]

12. Li J, Scott A, McGrail M et al. Retaining rural doctors: doctors' preferences for rural medical workforce incentives. Soc Sci Med 2014; 121: 56-64. [PubMed][CrossRef]

13. Matsumoto M, Inoue K, Kajii E. Policy implications of a financial incentive programme to retain a physician workforce in underserved Japanese rural areas. Soc Sci Med 2010; 71: 667-71.

[PubMed][CrossRef]

14. Christiansen TW, Sandvik H. Fastlegeordningen forvitrer - hva nå? Tidsskr Nor Legeforen 2017; 137. doi: 10.4045/tidsskr.17.0856. [PubMed][CrossRef]

15. St.meld. nr. 47 (2008-2009). Samhandlingsreformen: rett behandling - på rett sted - til rett tid. https://www.regjeringen.no/no/dokumenter/stmeld-nr-47-2008-2009-/id567201/ Lest 20.12.2019.

16. Statistisk sentralbyrå. Kortere pasientlister, lengre arbeidsdager? Rapport: Analyse SSB. 2018/14: Fastlegeordningen.

https://www.ssb.no/helse/artikler-og-publikasjoner/kortere-pasientlister-lengre-arbeidsdager Lest 10.12.2019.

17. Pedersen AF, Nørøxe KB, Bro F et al. Alment praktiserende lægers psykiske arbeidsmiljø og jobbtilfredshet 2016. Aarhus: Forskningsenheden for Almen Praksis, Aarhus Universitet, 2016. https://feap.au.dk/fileadmin/feap/Rapport_Praktiserende_laegers_arbejdsmiljoe_30.10.2016.pdf Lest 20.12.2019.

18. System och strategier för att öka antalet ST-läkare i allmänmedicin. Kunnskapsgrunnlag om hur vi kan nå balans i primärvårdens läkarförsörjing. Rapport. Stockholm: Sveriges läkarforbund, 2014. https://slf.se/app/uploads/2018/o5/rapport-om-st-lakare-i-allmanmedicin.pdf Lest 10.12.2019.

19. Owen K, Hopkins T, Shortland T et al. GP retention in the UK: a worsening crisis. Findings from a cross-sectional survey. BMJ Open 2019; 9: e026048. [PubMed][CrossRef]

20. Aasland OG, Rosta J. Fastlegenes arbeidstid 2000-08. Tidsskr Nor Legeforen 2011; 131:1076-9. [PubMed][CrossRef]

21. Rosta J, Aasland OG. Legers arbeidstid og tid til pasientarbeid i perioden 1994-2014. Tidsskr Nor Legeforen 2016; 136: 1355-9. [PubMed][CrossRef]

22. Hundskår S, red. Fastlegers tidsbruk. Rapport til Helsedirektoratet. Bergen: Uni Research Nasjonalt kompetansesenter for legevaktmedisin, 2018.

23. Kjosavik SR. Ongoing recruitment crisis In Norwegian general practice. Scand J Prim Health Care 2018;36:107-8. [PubMed][CrossRef]

24. Hertzberg TK, Tyssen R, Skirbekk H et al. Jobb-hjem-balanse i to kohorter av norske leger. Tidsskr Nor Legeforen 2019; 139. doi: 10.4045/tidsskr.18.0339. [PubMed][CrossRef]

25. Rosta J, Aasland OG, Nylenna M. Changes in job satisfaction among doctors in Norway from 2010 to 2017: a study based on repeated surveys. BMJ Open 2019; 9: eo27891. [PubMed][CrossRef]

26. Bårdvik M. Unge fastleger og kommuner hyller fastlønn-prosjekt. Dagens Medisin 31.8.2018.

https://www.dagensmedisin.no/artikler/2018/o8/31/unge-fastleger-og-kommuner-hyller-fastlonn-prosj ekt/ Lest 10.12.2019.

27. Dommerud T. Åpner for 200 flere stillinger for nyutdannede leger. Aftenposten 29.1.2019. https://www.aftenposten.no/norge/i/QleoMQ/Apner-for-20o-flere-stillinger-for-nyutdannede-leger Lest 10.12.2019.

28. Sinsky CA, Willard-Grace R, Schutzbank AM et al. In search of joy in practice: a report of 23 highfunctioning primary care practices. Ann Fam Med 2013; 11: 272-8. [PubMed][CrossRef]

29. Bodenheimer T, Sinsky C. From triple to quadruple aim: care of the patient requires care of the provider. Ann Fam Med 2014; 12: 573-6. [PubMed][CrossRef]

30. Brandstorp H. Rekruttering til fastlegeordningen. Aftenposten 27.5.2017.

https://www.aftenposten.no/meninger/debatt/i/x6BnQ/rekruttering-til-fastlegeordningen-helen-bran dstorp Lest 20.12.2019.

31. Allmennleger i spesialiering (ALIS). Rapport del 2 av 2. Oslo: Helsedirektoratet, 2018.

https://www.nsdm.no/wp-content/uploads/2019/o2/Allmennleger-i-spesialisering-ALIS-Del-2-av-2-ende 
lig-23645184_4_1.pdf Lest 20.12.2019.

32. Nilsen L. Dette kan bidra til en bedre rekruttering til allmennmedisin. Dagens Medisin 20.2.2018. https://www.dagensmedisin.no/artikler/2018/o2/20/-dette-kan-bidra-til-en-bedre-rekruttering-til-allme nnmedisin/ Lest 20.12.2019.

Publisert: 30. mars 2020. Tidsskr Nor Legeforen. DOI: 10.4045/tidsskr.19.0597 Mottatt 16.9.2019, første revisjon innsendt 4.10.2019, godkjent 12.2.2020.

(C) Tidsskrift for Den norske legeforening 2020. Lastet ned fra tidsskriftet.no 